\title{
Cancer mortality in a cohort of United Kingdom steel foundry workers: $1946-85$
}

\author{
T SORAHAN,' M A COOKE ${ }^{2}$
}

From the Cancer Epidemiology Research Unit, ${ }^{1}$ Department of Social Medicine, University of Birmingham, Edgbaston, Birmingham B15 2TJ, and Health and Safety Unit, ${ }^{2}$ Aston University, Birmingham B4 7ET, UK

ABSTRACT The mortality experienced by a cohort of 10491 United Kingdom steel foundry workers during the period 1946-85 has been investigated. These workers were all male operatives first employed in any one of the 10 participating foundries in 1946-65; all had worked in the industry for a minimum period of one year. Compared with the general population of England and Wales, statistically significant excesses relating to cancer mortality were found for cancer of the stomach $(E=77 \cdot 4, O=106, S M R=137)$ and cancer of the lung $(E=229 \cdot 2, O=441, S M R=147) . A$ statistically significant deficit was found for cancer of the brain $(E=19 \cdot 4, O=10, S M R=51)$. Involvement of occupational exposures was assessed by the method of regression models and life tables (RMLT). This method was used to compare the duration of employment in the industry, in "dust exposed" jobs, in "fume exposed" jobs, in foundry area jobs, in fettling shop jobs, and in foundry area or fettling shop jobs, of those dying from cancers of the stomach and lung with those of all matching survivors. The RMLT analyses provided evidence of an occupational involvement in the $\vec{\varphi}$ risk of death from lung cancer from work in the foundry area or fettling shop, and weaker evidence of $0_{0}^{\circ}$ an occupational involvement in the risk of death from stomach cancer from work in the foundry are

In 1983 a working group of the International Agency for Research on Cancer evaluated the carcinogenic risk of working in iron and steel founding. A report, published the following year, concluded: "The available epidemiological studies provide limited evidence that certain exposures in iron and steel founding are carcinogenic to humans, giving rise to lung cancer. There is inadequate evidence that such exposures result in cancers of the digestive system and genitourinary system. A number of individual compounds for which there is sufficient evidence of carcinogenicity have been measured at high levels in air samples taken from certain areas in iron and steel foundries. Taken together, the available evidence indicates that occupational exposures occur in iron and steel founding which are probably carcinogenic to humans."

The epidemiological studies available for the above evaluation included published reports of mortality among cohorts of foundry workers from North America, ${ }^{2-10}$ Scandinavia, ${ }^{11-12}$ and the United Kingdom. ${ }^{13}$ It is this latter study which is updated here.

Accepted 18 January 1988

\section{Study population}

The study population has been described elsewhere, ${ }^{13} \stackrel{3}{3}$ but may be summarised as all male operatives who started work in 10 steel foundries (nine Englisho foundries and one Scottish foundry) between 1946 and $\bar{O}$ 1965 , who were employed for at least one year. Office $\frac{\mathbb{N}}{3}$ staff and management were excluded. All foundries were members of the Steel Castings Research and 3 . Trade Association (SCRATA), which has provided financial and technical help at various times in the history of this study.

Detailed job histories-defined in terms of $25 \stackrel{\circ}{\circ}$ categories (table 1)-were recorded for each $\frac{D}{0}$ employee.

Follow up procedures have also been described $\mathcal{N}^{\circ}$ elsewhere. ${ }^{13}$ Vital status was supplied by the National $N$ Health Service Central Register (NHSCR). For those $N$ "no trace" at the NHSCR, vital status was sought $\omega$ from the National Insurance records held by the Department of Health and Social Security (DHSS).

Table 2 shows the vital status of the study popula- $\mathbb{D}$ tion on the closing date of the study, 31 December 1985. For those known to have died, a death certificate 
Table 1 Classification of jobs

\begin{tabular}{|c|c|}
\hline Category & Range of occupational titles \\
\hline \multicolumn{2}{|r|}{ Foundry } \\
\hline Sand preparation * & $\begin{array}{l}\text { Sand miller, sand plant service labourer, } \\
\text { millman mixer }\end{array}$ \\
\hline Moulding*† & $\begin{array}{l}\text { Moulder, coremaker, closer, machine } \\
\text { moulder, pinlift, shellmoulder, shell } \\
\text { coremaker, closer, flame dryer, corestove } \\
\text { attendant }\end{array}$ \\
\hline Furnace $\dagger$ & $\begin{array}{l}\text { Furnaceman, 2nd hand, 3rd hand, } \\
\text { spareman, scrapman, ladleman, teemer, } \\
\text { caster, ingot man, cupola loader, labourer } \\
\text { (steel plant) }\end{array}$ \\
\hline Furnace repair* & $\begin{array}{l}\text { Furnace fettler, patcher, furnace bricklayer, } \\
\text { furnace fitter's mate, furnace serviceman }\end{array}$ \\
\hline Centrifugal casting & $\begin{array}{l}\text { Spinner, spinning operator, puller out, } \\
\text { single end shanker }\end{array}$ \\
\hline $\begin{array}{l}\text { Foundry cranest } \\
\text { Labourers, etc }\end{array}$ & $\begin{array}{l}\text { Cranedriver, -mobile crane driver } \\
\text { Foundry labourer, fork lift driver, slinger, } \\
\text { degreaser's labourer, steel carrier }\end{array}$ \\
\hline $\begin{array}{l}\text { Knockout }{ }^{*}+ \\
\text { Other }\end{array}$ & $\begin{array}{l}\text { Knocker out, knockout labourer, gridman } \\
\text { Alloy storekeeper, descaler, die inspector, } \\
\text { chip crusher }\end{array}$ \\
\hline \multicolumn{2}{|r|}{ Fettling shop } \\
\hline $\begin{array}{l}\text { Fettling* } \\
\text { Blasting* }\end{array}$ & $\begin{array}{l}\text { Fettler, grinder, finisher, dresser, chipper } \\
\text { Shot blaster, hydroblaster, wheelabrator }\end{array}$ \\
\hline Burning and welding $†$ & $\begin{array}{l}\text { Burner, welder, cutter, powder washer, oxy- } \\
\text { cutter, arc air gouger }\end{array}$ \\
\hline Heat treatment $\dagger$ & $\begin{array}{l}\text { Heat treatment furnaceman, loader, stove } \\
\text { attendant (heat treatment), heat } \\
\text { treatment labourer }\end{array}$ \\
\hline Fettling shop cranes $\dagger$ & Crane driver \\
\hline Labourers, etc ${ }^{*} \dagger$ & $\begin{array}{l}\text { Labourer, service labourer, fork lift driver, } \\
\text { press operator assistant, link wrapper, } \\
\text { setter's assistant }\end{array}$ \\
\hline Other & $\begin{array}{l}\text { Blacksmith, dressing shop inspector, setter, } \\
\text { stamper, checker, blacksmith striker }\end{array}$ \\
\hline \multicolumn{2}{|c|}{ Pattern/machine/maintenance/inspection } \\
\hline Pattern maker & Pattern maker \\
\hline Pattern shop labourer & $\begin{array}{l}\text { Pattern labourer, pattern storeman, } \\
\text { labourer, pattern stores, pattern checker }\end{array}$ \\
\hline Inspection & $\begin{array}{l}\text { Checker, inspector, machinist (inspection), } \\
\text { labourer (crack detection), marker off, } \\
\text { pressure test, test press assistant }\end{array}$ \\
\hline Machining & $\begin{array}{l}\text { Turner, machinist, driller, machine shop } \\
\text { fitter, miller, borer }\end{array}$ \\
\hline $\begin{array}{l}\text { Machine shop } \\
\text { labourers etc }\end{array}$ & $\begin{array}{l}\text { Labourer, fork lift truck driver, crane } \\
\text { driver, machine shop storekeeper, } \\
\text { inspector }\end{array}$ \\
\hline $\begin{array}{l}\text { Welding } \dagger \\
\text { Maintenance }\end{array}$ & $\begin{array}{l}\text { Machine shop welder, maintenance welder } \\
\text { Maintenance fitter, electrician, joiner, } \\
\text { blacksmith, pipe fitter }\end{array}$ \\
\hline Maintenance mates & $\begin{array}{l}\text { Fitter's mate, maintenance craftsman's } \\
\text { mate, greaser, belt attendant }\end{array}$ \\
\hline Other & $\begin{array}{l}\text { Yard labourer, lorry driver, storekeeper, } \\
\text { yard bricklayer, despatch labourer, } \\
\text { boilerman, tackle shop, assistant blower } \\
\text { house attendant }\end{array}$ \\
\hline
\end{tabular}

* Jobs attracting higher dust exposure.

†Jobs attracting higher fume exposure.

was obtained with the cause of death coded to the 8th revision of the International Classification of Diseases.

The study population had originally included a further group of 626 workers with Indian, Pakistani, or Arab surnames. Overall mortality was found to be suspiciously low for this group $(\operatorname{Exp}=87.6$, Obs $=35, \operatorname{SMR}=40$ ) and these workers have,
Table 2 Vital status at closing date of study (31 December 1985)

\begin{tabular}{lrr}
\hline & \multicolumn{1}{l}{ No } & \multicolumn{1}{l}{$\%$} \\
\hline "Flagged" alive at the NHSCR & 6833 & $65 \cdot 2$ \\
Traced alive at the NI offices & 192 & 1.8 \\
Emigrated & 204 & 1.9 \\
No trace & 129 & $1 \cdot 2$ \\
Died, cause known & 3110 & $29 \cdot 7$ \\
Died, cause not known & 23 & $0 \cdot 2$ \\
Total & 10491 & $100 \cdot 0$ \\
\hline
\end{tabular}

therefore, been excluded from all analyses detailed in this report.

Methods

The mortality experience of this cohort was compared with that which might have been expected to occur if rates of death for the general population of England and Wales had been operating on the study cohort, having due regard to the composition of the study cohort by age, sex, and calendar year.

Expectations based on person-years at risk (pyr) were calculated using the Manyears computer program developed by J Peto. Individuals entered the pyr at the end of the first year of employment and left on the date of death, date of embarkation, "date last known alive," or the closing date of the study, whichever was the earlier. Individuals were "censored" on reaching their 85th birthday-that is, they make no further contributions to expected or observed numbers past this age. This was done for two reasons: firstly, national death rates are only available for the "open ended" age group " $\geqslant 85$," the composition of which in the general population by individual years of age may differ greatly from that of the study population and, secondly, any individual incorrectly traced, for whatever reason, as still living would make a particularly large contribution to expectations for this age group.

This placed the mortality experience of the study cohort in broad perspective. The differences found, however, between the mortality of an industrial cohort and an expected experience based on rates of mortality for the general population also depend on factors other than the specific occupational exposure. Such factors will include selection effects within the workforce as well as the regional, urban/rural, and social class composition of the study cohort. The method of regression models in life tables (RMLT) was used, therefore, to test the null hypothesis of no effect on mortality from duration of "exposed" employment in the industry, contrasting groups from within the study population. ${ }^{14-18}$ This approach was used because, by relying on internal comparisons, we believe that we 
Table 3 Steel foundry workers: cancer mortality, 1946-85

\begin{tabular}{|c|c|c|c|c|}
\hline Site & $I C D 8 t h$ & Obs & Exp & $S M R$ \\
\hline $\begin{array}{l}\text { Lip } \\
\text { Tongue } \\
\text { Mouth } \\
\text { Pharynx } \\
\text { Oesophagus } \\
\text { Stomach } \\
\text { Small intestine } \\
\text { Large intestine } \\
\text { Rectum } \\
\text { Liver } \\
\text { Gallbladder } \\
\text { Pancreas } \\
\text { Nose, sinuses } \\
\text { Larynx } \\
\text { Lung } \\
\text { Bone } \\
\text { Skin } \\
\text { Breast } \\
\text { Prostate } \\
\text { Testis } \\
\text { Bladder } \\
\text { Other genital } \\
\text { Other urinary } \\
\text { Brain } \\
\text { Thyroid } \\
\text { Lympho } \\
\text { Hodgkins } \\
\text { Myeloma } \\
\text { Leukaemia }\end{array}$ & $\begin{array}{l}140 \\
141 \\
143-5 \\
146-9 \\
150 \\
151 \\
152 \\
153 \\
154 \\
155 \\
156 \\
157 \\
160 \\
161 \\
162,3 \\
170 \\
172,3 \\
174 \\
185 \\
186 \\
188 \\
187 \\
189 \\
191,2 \\
193 \\
200,202 \\
201 \\
203 \\
204-207\end{array}$ & $\begin{array}{c}0 \\
4 \\
2 \\
3 \\
15 \\
106^{* *} \\
1 \\
40 \\
40 \\
2 \\
3 \\
34 \\
4 \\
8 \\
441^{* * *} \\
1 \\
3 \\
0 \\
22 \\
3 \\
25 \\
0 \\
14 \\
10\left(^{*}\right) \\
2 \\
12 \\
5 \\
9 \\
14\end{array}$ & $\begin{array}{r}0 \cdot 3 \\
2 \cdot 4 \\
2 \cdot 2 \\
5 \cdot 1 \\
21 \cdot 2 \\
77 \cdot 4 \\
1 \cdot 5 \\
43 \cdot 4 \\
33 \cdot 3 \\
4 \cdot 9 \\
4 \cdot 2 \\
31 \cdot 2 \\
1 \cdot 6 \\
6 \cdot 9 \\
299 \cdot 2 \\
2 \cdot 6 \\
6 \cdot 5 \\
0 \cdot 9 \\
31 \cdot 5 \\
3 \cdot 1 \\
26 \cdot 2 \\
1 \cdot 1 \\
13 \cdot 4 \\
19 \cdot 4 \\
1 \cdot 3 \\
14 \cdot 1 \\
7 \cdot 0 \\
7 \cdot 4 \\
17 \cdot 6\end{array}$ & $\begin{array}{c}0 \\
170 \\
90 \\
59 \\
71 \\
137 \dagger \\
65 \\
92 \\
120 \\
41 \\
71 \\
109 \\
251 \\
116 \\
147 \dagger \\
39 \\
46 \\
0 \\
70 \\
97 \\
96 \\
0 \\
105 \\
51 \\
149 \\
85 \\
72 \\
122 \\
79\end{array}$ \\
\hline All cancers & $140-209$ & $862^{* * *}$ & 726.8 & 119 \\
\hline
\end{tabular}

Two tailed tests: ${ }^{*} p<0.05 ;{ }^{* *} p<0.01 ;{ }^{* * *} p<0.001$

() indicates significant deficit.

†The use of Scottish rates of mortality for the Scottish foundry provided overall SMRs of 136 and 146 for cancer of the stomach and cancer of the lung respectively.

may control for selection effects, and regional, urban/ rural, and social class effects.

The method ${ }^{15-18}$ was used to compare the duration of exposed employment of those who died from the cause under investigation with those of all matching survivors, while controlling for year of starting employment (1946-50, 1951-5, 1956-60, 1961-5), age at starting employment (15-, 20-, 25-, 30-, 35-, 45-, $\geqslant 55$ ), factory ( 10 participating factories), and year of follow up. In some instances it was also possible to include "duration of employment in the industry" as a controlling factor, to try and control for any "survivor population effect" in the data.

Expert advice was sought on the most appropriate classification of job titles into $(a)$ those jobs attracting higher dust exposures and (b) those jobs attracting higher fume exposures. Our overall classification is shown in table 1. Four of the participating foundries suggested that slight modifications in the classification would be appropriate for their particular foundry, and these modifications were accepted. Individual factories will differ in terms of chemicals found in the workplace, factory operating procedures, and lay out of the factory. There will also be changes over time. The classification, then, is a broad classification.
The data were first divided into a large number of $\overline{\bar{\alpha}}$ subgroups by levels of the controlling variables mentioned above. For each subgroup (or subcohort) $\mathrm{a}_{\propto}^{\widehat{\Phi}}$ life table was constructed, giving for each year of follow up the number entering that year of follow up, $\stackrel{5}{\rightarrow}$ the number dying from the cause under investigation, and the mean duration of exposed employment of these two categories.

Extent of occupational exposure was estimated in five ways:

(1) cumulative duration of employment in the industry (irrespective of which departments were worked in);

(2) cumulative duration of employment in jobso attracting higher levels of dust exposure (see table 1);

(3) cumulative duration of employment in jobs 3 attracting higher levels of fume exposure (see table 1);

(4) cumulative duration of employment in foundryî area jobs;

(5) cumulative duration of employment in fettlingo shop jobs; and

Table 4 Mortality from stomach cancer by first occupational category

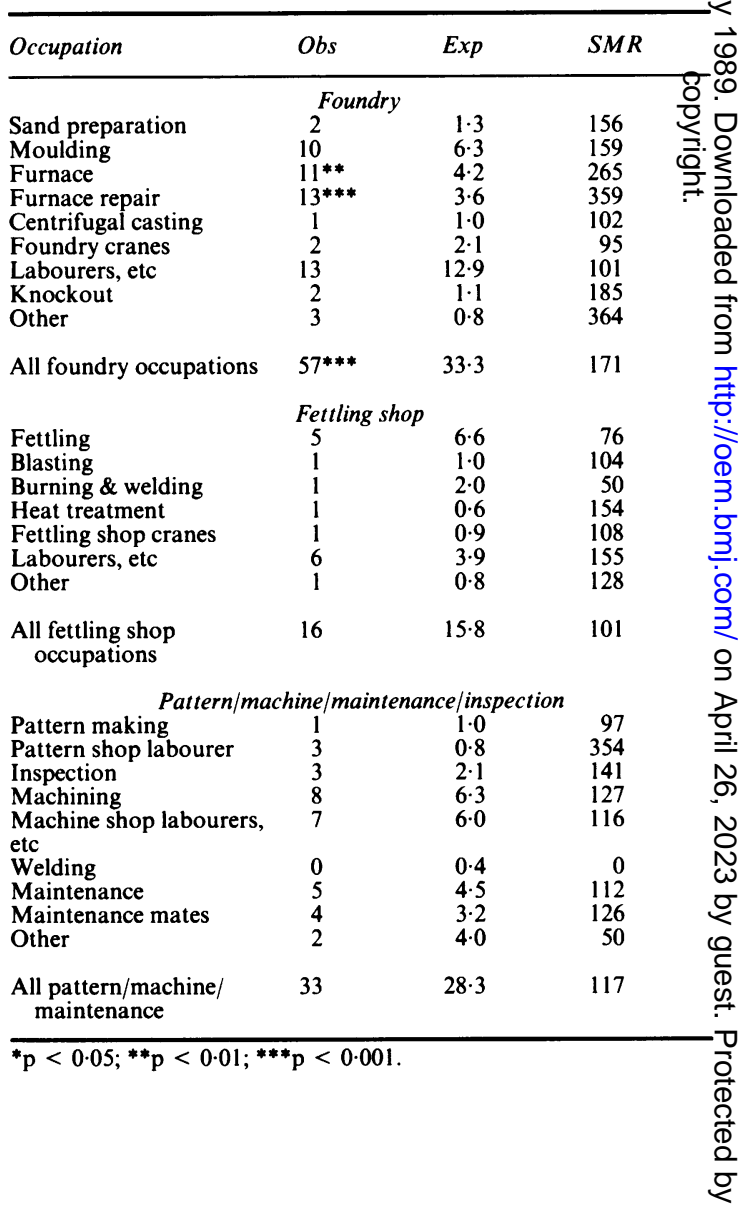


Table 5 Mortality from lung cancer by first occupational category

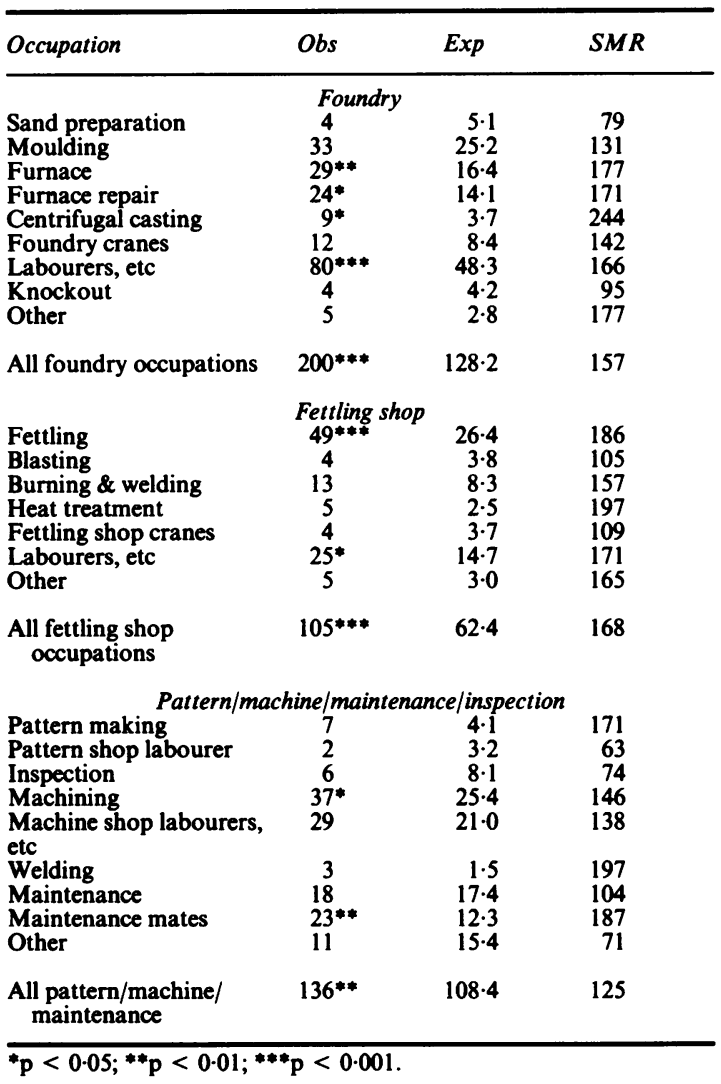

(6) cumulative duration of employment in foundry area or fettling shop jobs.

The null hypothesis of no effect on mortality from duration of exposed employment is that the deaths in each year are a random sample from the entrants to that year, and that the differences in the mean cumulative duration of exposed employment of these two categories should be zero.

A test statistic was calculated to determine the probability of observing by chance alone the differences found between the duration of exposed employment of those who have died and the duration of exposed employment of the matching survivorsthat is, if the null hypothesis of no effect on mortality from duration of exposed employment is true. Thus with a test statistic greater than \pm 1.96 , the null hypothesis is rejected at the $5 \%$ level.

A positive test statistic indicates that deaths from the cause under investigation tend to occur among those with longer periods of exposed employment, which could be due to the existence of an occupational risk factor, or bias, or confounding, or chance. A negative test statistic indicates that deaths from the cause under investigation are tending to occur among those with shorter periods of exposed employment, which could be due to the existence of protective occupational exposures, or bias, or confounding, or chance.

\section{Results}

\section{SMR APPROACH}

The existence of any healthy worker effect in the data is best investigated by calculating SMRs for successive periods from first employment (irrespective of how long any individual remains in the industry). ${ }^{19}$ For successive 10 year periods from first employment, SMRs for all cancers were 105, 136, 109 and 119 respectively, and SMRs for all non-cancers were 95, 117,111 , and 111 respectively. Although SMRs for these two broad cause of death groupings are lowest in the 10 year period following first employment, a general trend of increase is not shown over the follow up period. There is, then, only limited evidence of a healthy worker effect in these data.

Table 3 shows overall results for cancer mortality by site. Compared with the general population, there are statistically significant excesses for cancer of the stomach, cancer of the lung, and all cancers and a statistically significant deficit for cancer of the brain.

Table 4 shows observed and expected numbers of deaths by first occupation for cancer of the stomach. The excess is found predominantly in foundry occupations (all foundry occupations, SMR = 171) and, in particular, "furnace" and "furnace repair."

Table 5 shows observed and expected numbers of deaths by first occupation for cancer of the lung. SMRs are higher for all foundry occupations $(S M R=157)$ and all fettling shop occupations $(S M R=168)$ than for pattern/machine/ maintenance/inspection $\quad(S M R=125)$, although statistically significant excesses are shown for several occupations within each of these three broad categories (foundry: furnace, furnace repair, centrifugal casting, labourers etc; fettling shop: fettling, labourers etc; pattern/machine/maintenance/ inspection: machining, maintenance mates).

Table 6 shows observed and expected numbers of deaths for stomach cancer and lung cancer by entry cohort and by successive 10 year periods from first employment. For stomach cancer, SMRs tend to be higher 10-19 years from first employment, with little evidence of excess mortality 20 years or more from first employment. For lung cancer, there is evidence, among three of the four cohorts, of a trend of SMRs increasing with period from first employment.

Table 7 shows observed and expected numbers of 
Table 6 Steel foundry workers: mortality from stomach cancer and lung cancer 1946-85 by entry cohort and by years from first employment

\begin{tabular}{|c|c|c|c|c|c|c|c|c|c|c|}
\hline \multirow[b]{2}{*}{$\begin{array}{l}\text { Years from } \\
\text { first employment* }\end{array}$} & \multicolumn{8}{|c|}{ Entry cohort } & \multirow[b]{2}{*}{$\begin{array}{l}\text { Total } \\
\text { SMR }\end{array}$} & \multirow[b]{2}{*}{$(O)$} \\
\hline & $\begin{array}{l}1946-50 \\
S M R\end{array}$ & $(O)$ & $\begin{array}{l}1951-5 \\
S M R\end{array}$ & $(0)$ & $\begin{array}{l}1956-60 \\
S M R\end{array}$ & $(O)$ & $\begin{array}{l}1961-5 \\
S M R\end{array}$ & $(O)$ & & \\
\hline $\begin{array}{l}\text { Cancer of stomach: } \\
0-9 \\
10-19 \\
20-29 \\
\geqslant 30\end{array}$ & $\begin{array}{l}224 \\
150 \\
119 \\
110\end{array}$ & $\begin{array}{r}(8) \\
(10) \\
(11) \\
(9)\end{array}$ & $\begin{array}{r}86 \\
214 \\
118 \\
90\end{array}$ & $\begin{array}{r}(4) \\
(18) \\
(13) \\
(3)\end{array}$ & $\begin{array}{r}164 \\
214 \\
54 \\
-\end{array}$ & $\begin{array}{r}(5) \\
(12) \\
(3) \\
-\end{array}$ & $\begin{array}{r}82 \\
162 \\
80 \\
-\end{array}$ & $\begin{array}{l}(2) \\
(7) \\
(1) \\
-\end{array}$ & $\begin{array}{l}139 \\
188 \\
103 \\
104\end{array}$ & $\begin{array}{l}(19) \\
(47) \\
(28) \\
(12)\end{array}$ \\
\hline Total & 137 & (38) & 139 & (38) & 140 & (20) & 125 & (10) & 137 & (106) \\
\hline $\begin{array}{l}\text { Cancer of lung: } \\
0-9 \\
10-19 \\
20-29 \\
\geqslant 30\end{array}$ & $\begin{array}{l}106 \\
126 \\
124 \\
142\end{array}$ & $\begin{array}{l}(9) \\
(27) \\
(45) \\
(52)\end{array}$ & $\begin{array}{l}119 \\
155 \\
154 \\
169\end{array}$ & $\begin{array}{l}(16) \\
(47) \\
(72) \\
(25)\end{array}$ & $\begin{array}{l}163 \\
199 \\
145 \\
-\end{array}$ & $\begin{array}{l}(17) \\
(44) \\
(36) \\
-\end{array}$ & $\begin{array}{l}120 \\
146 \\
233 \\
-\end{array}$ & $\begin{array}{l}(11) \\
(27) \\
(13) \\
-\end{array}$ & $\begin{array}{l}127 \\
157 \\
146 \\
149\end{array}$ & $\begin{array}{r}(53) \\
(145) \\
(166) \\
(77)\end{array}$ \\
\hline Total & 129 & (133) & 152 & $(160)$ & 169 & (97) & 154 & (51) & 147 & (441) \\
\hline
\end{tabular}

deaths for stomach cancer and lung cancer by first work area and by successive 10 year periods from first employment. For stomach cancer, the highest SMR is shown for all foundry occupations 10-19 years from first employment. SMRs for all fettling shop occupations decrease with time from first employment. For lung cancer, similar SMRs are shown for the foundry area but for the fettling shop there is a tendency for SMRs to increase with period from first employment.

\section{RMLT APPROACH}

The method of regression models and life tables (RMLT) was used to investigate any association between the risk of death from lung cancer and stomach cancer and duration of employment in the industry or duration of employment in various job categories.

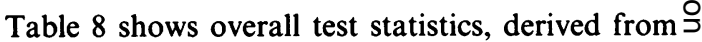
comparing the duration of employment (variously $\overrightarrow{-}$ defined) of those dying from lung cancer, stomach $\mathbb{D}$ cancer, or all causes with those of all matching survivors. No statistically significant positive test statistics were found, although the test statistic shown for cancer of the stomach and duration of employment $\vec{\varnothing}$ in the foundry area approached significan\&e $\subseteq$ $(\mathrm{t}=+1 \cdot 74, \mathrm{p}=0.08)$, as did that for cancer of the lung and duration of employment in the foundry arề or fettling shop $(t=+1 \cdot 66, p=0 \cdot 10)$. For each $\overline{\partial f} \frac{\partial}{0}$ the six test factors shown, the mean difference in duration of exposed employment between deaths and $\stackrel{2}{\square}$ matching survivors was larger (in the positive direc- $\overrightarrow{\vec{A}}$ tion) for lung cancer than it was for all causes.

A further test statistic was calculated for cancer of the stomach and duration of employment in the

Table 7 Steel foundry workers: mortality from stomach cancer and lung cancer 1946-85 by first work area and by years from first employment

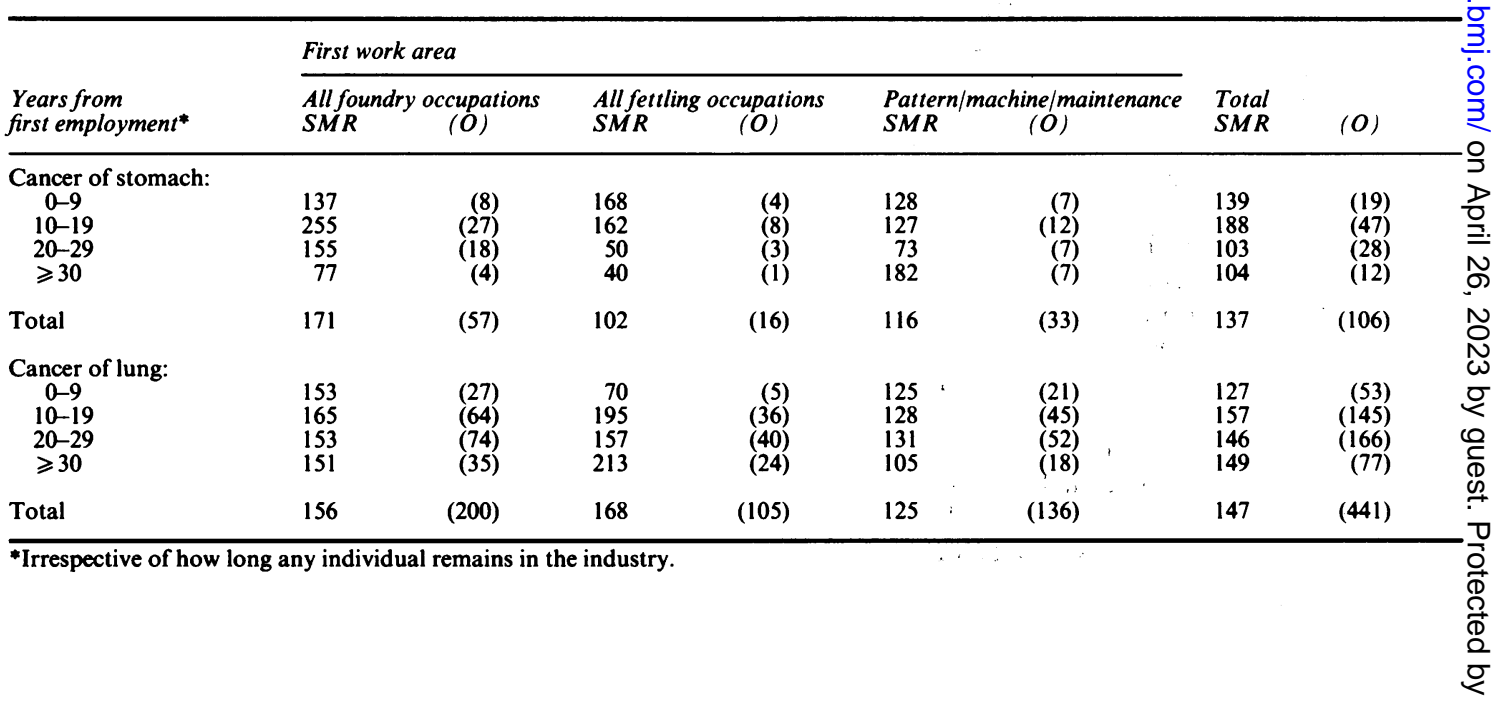


Table 8 Testing the null hypothesis of no effect from duration of employment in various job groupings on risk of death from stomach cancer, lung cancer, and all causes, by the method of RMLT†

\begin{tabular}{|c|c|c|c|}
\hline $\begin{array}{l}\text { Cause of death (No of deaths) } \\
\text { and test factor } \ddagger\end{array}$ & $\begin{array}{l}\text { Mean } \\
\text { duration } \\
\text { of exposed } \\
\text { employment } \\
\text { of deaths§ }\end{array}$ & $\begin{array}{l}\text { Mean } \\
\text { difference } \\
\text { between } \\
\text { deaths and } \\
\text { tmatching } \\
\text { survivors }\end{array}$ & $\begin{array}{l}\text { Test } \\
\text { statistic\| }\end{array}$ \\
\hline $\begin{array}{l}\text { Cancer of stomach }(\mathrm{n}=106) \text { : } \\
\text { Industry } \\
\text { Dust exposed jobs } \\
\text { Fume exposed jobs } \\
\text { Foundry area } \\
\text { Fettling shop } \\
\text { Foundry area and/or fettling } \\
\text { shop }\end{array}$ & $\begin{array}{l}7.1 \\
1.9 \\
1.8 \\
3.4 \\
1.0 \\
4.4\end{array}$ & $\begin{array}{l}-0.9 \\
-0.2 \\
-0.1 \\
+0.7 \\
-0.5 \\
+0.2\end{array}$ & $\begin{array}{l}-1.42 \\
-0.54 \\
-0.28 \\
+1.74 \\
-1.42 \\
+0.51\end{array}$ \\
\hline $\begin{array}{l}\text { Cancer of lung }(n=441) \text { : } \\
\text { Industry } \\
\text { Dust exposed jobs } \\
\text { Fume exposed jobs } \\
\text { Foundry area } \\
\text { Fettling shop } \\
\text { Foundry area and/or fettling } \\
\text { shop }\end{array}$ & $\begin{array}{l}8 \cdot 8 \\
3 \cdot 2 \\
2 \cdot 8 \\
3 \cdot 7 \\
2 \cdot 4 \\
6 \cdot 1\end{array}$ & $\begin{array}{l}-0.2 \\
+0.3 \\
+0.1 \\
+0.2 \\
+0.2 \\
+0.4\end{array}$ & $\begin{array}{l}-0.46 \\
+1.27 \\
+0.35 \\
+0.88 \\
+0.95 \\
+1.66\end{array}$ \\
\hline $\begin{array}{l}\text { All causes }(n=3102) \\
\text { Industry } \\
\text { Dust exposed jobs } \\
\text { Fume exposed jobs } \\
\text { Foundry area } \\
\text { Fettling shop } \\
\text { Foundry area and/or fettling } \\
\text { shop }\end{array}$ & $\begin{array}{l}8 \cdot 5 \\
2 \cdot 8 \\
2 \cdot 3 \\
3 \cdot 3 \\
2 \cdot 0 \\
5 \cdot 3\end{array}$ & $\begin{array}{r}-0.3 \\
+0.1 \\
-0.2 \\
-0.1 \\
0.0 \\
0.0\end{array}$ & $\begin{array}{l}-2.77\left(^{* *}\right) \\
+0.67 \\
-2.49\left(^{*}\right) \\
-0.69 \\
+0.43 \\
-0.29\end{array}$ \\
\hline
\end{tabular}

*p $<0.05 ; *{ }^{*} \mathrm{p}<0.01$. ( ) = Significant negative statistic.

†Controlling for age at hire $(15-, 20-, 25-, 30-, 35-, 45-, \geqslant 55)$, year of hire (1946-50, 1951-5, 1956-60, 1961-5), foundry (10 participating foundries). For test factors 2-6 inclusive, also controlling for duration of employment in the industry $(1-2,3-7$, $\geqslant 8$ years).

tSee table 1.

$\S$ In units of years of employment in jobs defined by the various test factors.

|Asymptotically normally distributed.

foundry area, with periods of exposed employment "lagged" by ten years. Table 9 shows contributions from subcohorts to the overall test statistics both for lagged and unlagged periods of exposed employment. The overall test statistic for lagged exposures was reduced to +1.62 , although the test statistic for the period 10-19 years from first employment was increased from +1.83 to $+2.37(\mathrm{p}=0.06$ to $\mathrm{p}=0.02$ ). Statistically significant test statistics are also shown for the most recent entry cohort (first employed 1961-5) and for short term workers. These are not mutually exclusive categories.

The results of a similar analysis are shown in table 10 for lung cancer and duration of employment in the foundry area or fettling shop. The overall test statistic for lagged exposures was increased to +2.33 $(p<0.05)$. Statistically significant test statistics are also shown for the earlier entry cohort (first employed
1946-50) and for long term workers. These are not mutually exclusive categories.

Test statistics for the first three test factors were also calculated for cancer of the oesophagus, cancer of the bladder, all reticuloendothelial systems neoplasms, all cancers, diseases of the circulatory system, and diseases of the respiratory system (non-malignant). No statistically significant positive statistics were obtained.

\section{Discussion}

A general discussion of the methodology used in this analysis may be found elsewhere. ${ }^{17}$ Cancers of the stomach and of the lung were chosen for more detailed

Table 9 Testing the null hypothesis of no effect from duration of employment in foundry area jobs on risk of death from stomach cancer, by the method of RMLTY. Results shown by controlling variables for unlagged and lagged periods of exposed employment

\begin{tabular}{|c|c|c|c|c|}
\hline Controlling variables & $\begin{array}{l}\text { No of } \\
\text { deaths }\end{array}$ & $\begin{array}{l}\text { Mean } \\
\text { duration } \\
\text { of exposed } \\
\text { employment } \\
\text { of deaths }\end{array}$ & $\begin{array}{l}\text { Mean } \\
\text { difference } \\
\text { between } \\
\text { deaths and } \\
\text { t matching } \\
\text { survivors }\end{array}$ & $\begin{array}{l}\text { Test } \\
\text { statistic }\end{array}$ \\
\hline \multicolumn{5}{|c|}{ With unlagged periods of exposed employment } \\
\hline $\begin{array}{l}\text { By entry cohort } \\
1946-50 \\
1951-55 \\
1956-60 \\
1961-65\end{array}$ & $\begin{array}{l}38 \\
38 \\
20 \\
10\end{array}$ & $\begin{array}{l}3 \cdot 3 \\
3 \cdot 9 \\
1 \cdot 8 \\
5 \cdot 5\end{array}$ & $\begin{array}{l}+0.3 \\
+1.2 \\
-0.4 \\
+2.8\end{array}$ & $\begin{array}{l}+0.40 \\
+1 \cdot 72 \\
-0.48 \\
+2 \cdot 30^{*}\end{array}$ \\
\hline \multicolumn{5}{|c|}{$\begin{array}{l}\text { By duration of employment } \\
\text { in the industry }(y)\end{array}$} \\
\hline $\begin{array}{l}1-2 \\
3-7 \\
\geqslant 8\end{array}$ & $\begin{array}{l}39 \\
33 \\
34\end{array}$ & $\begin{array}{l}1 \cdot 2 \\
2.5 \\
6.9\end{array}$ & $\begin{array}{l}+0.3 \\
+0.7 \\
+1.3\end{array}$ & $\begin{array}{l}+2.14^{*} \\
+1.62 \\
+1.02\end{array}$ \\
\hline \multicolumn{5}{|l|}{$\begin{array}{l}\text { By period from first } \\
\text { employment (y) }\end{array}$} \\
\hline $\begin{array}{l}0-9 \\
10-19 \\
\geqslant 20\end{array}$ & $\begin{array}{l}19 \\
47 \\
40\end{array}$ & $\begin{array}{l}1 \cdot 5 \\
3 \cdot 7 \\
4 \cdot 0\end{array}$ & $\begin{array}{l}+0.3 \\
+1.1 \\
+0.6\end{array}$ & $\begin{array}{l}+0.74 \\
+1.83 \\
+0.65\end{array}$ \\
\hline Total & 106 & $3 \cdot 4$ & +0.7 & +1.74 \\
\hline \multicolumn{5}{|c|}{ With periods of exposed employment lagged by 10 years } \\
\hline $\begin{array}{l}\text { By entry conort } \\
1946-50 \\
1951-55 \\
1956-60 \\
1961-65\end{array}$ & $\begin{array}{l}38 \\
38 \\
20 \\
10\end{array}$ & $\begin{array}{l}2 \cdot 4 \\
2 \cdot 5 \\
1 \cdot 3 \\
2 \cdot 1\end{array}$ & $\begin{array}{l}+0.3 \\
+0.7 \\
+0.1 \\
+1.1\end{array}$ & $\begin{array}{l}+0.52 \\
+1.39 \\
+0.15 \\
+2.38^{*}\end{array}$ \\
\hline \multicolumn{5}{|c|}{$\begin{array}{l}\text { By duration of employment } \\
\text { in the industry }(y)\end{array}$} \\
\hline $\begin{array}{l}1-2 \\
3-7 \\
\geqslant 8\end{array}$ & $\begin{array}{l}39 \\
33 \\
34\end{array}$ & $\begin{array}{l}0.9 \\
1.5 \\
4 \cdot 2\end{array}$ & $\begin{array}{l}+0.3 \\
+0.5 \\
+0.7\end{array}$ & $\begin{array}{l}+2.18^{*} \\
+1.52 \\
+0.86\end{array}$ \\
\hline \multicolumn{5}{|l|}{$\begin{array}{l}\text { By period from first } \\
\text { employment }(y)\end{array}$} \\
\hline $\begin{array}{l}0-9 \\
10-19 \\
\geqslant 20\end{array}$ & $\begin{array}{l}19 \\
47 \\
40\end{array}$ & $\begin{array}{l}\mathrm{n} / \mathrm{a} \\
1.9 \\
3.6\end{array}$ & $\begin{array}{l}n / a \\
+0.6 \\
+0.5\end{array}$ & $\begin{array}{l}\text { n/a } \\
+2.37^{*} \\
+0.72\end{array}$ \\
\hline Total & 106 & $2 \cdot 2$ & +0.5 & +1.62 \\
\hline
\end{tabular}


Table 10 Testing the null hypothesis of no effect from duration of employment in foundry area or fettling shop jobs on risk of death from lung cancer by the method of RMLTY. Results shown by controlling variables for unlagged and lagged periods of exposed employment

\begin{tabular}{|c|c|c|c|c|}
\hline Controlling variables & $\begin{array}{l}\text { No of } \\
\text { deaths }\end{array}$ & $\begin{array}{l}\text { Mean } \\
\text { duration } \\
\text { of exposed } \\
\text { employment } \\
\text { of deaths§ }\end{array}$ & $\begin{array}{l}\text { Mean } \\
\text { difference } \\
\text { between } \\
\text { deaths and } \\
\text { tmatching } \\
\text { survivors }\end{array}$ & $\begin{array}{l}\text { Test } \\
\text { statistic } \|\end{array}$ \\
\hline
\end{tabular}

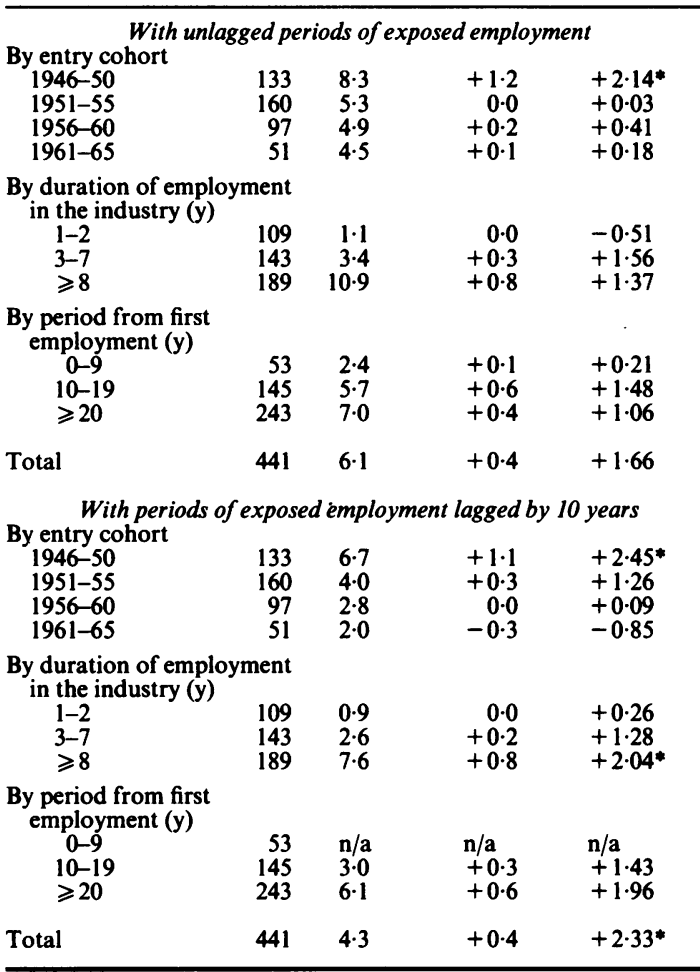

*p <0.05.†; $\|$ : see table 8 .

şn units of years of employment in foundry area or fettling shop jobs (see table 1).

analysis on the basis of both the high overall SMRs obtained in this study and the published findings from other studies. ${ }^{\prime}$ The test factors considered in the RMLT analysis were known to be relatively crude, although believed to merit consideration.

Some suggestive evidence of an occupational involvement in death from cancer of the stomach from working in the foundry area was provided both by the SMR and the RMLT analyses. This hypothesis was not supported, however, by the unexceptional SMRs shown for the period 20 years or more from first employment, nor by finding the more significant RMLT test statistics among short term (rather than long term) workers.
The RMLT analysis of employment in the foundry $\underline{2}$ area or fettling shop, provided more convincing $\frac{3}{\infty}$ evidence of an occupational involvement in mortality ? for cancer of the lung. Attempts at uncovering a more $\overrightarrow{\vec{B}}$ specific work association were unsuccessful.

Data on smoking histories were unfortunately not available, although there is no good reason to believe $\frac{\bar{\sigma}}{\bar{N}}$ that they would correlate with any of the test factors $\vec{\sigma}$

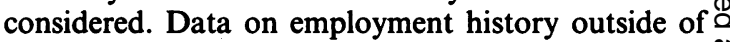
the 10 study foundries were also unavailable. This may $\%$ be a serious limitation, particularly if our short term $\overrightarrow{0}$ foundry workers moved on to foundry work elsewhere.

In conclusion, the RMLT analyses provided evidence of an occupational involvement in lung $\Phi$ cancer mortality from working in the foundry area or fettling shop, and weaker evidence of an occupational $\vec{\sigma}$ involvement in stomach cancer mortality from work- ? ing in the foundry area.

Although there are obvious practical problems in 의 gaining a detailed historical assessment of work processes, practices, and conditions at each of the $10 T_{\mathbb{D}}$ participating foundries, such an assessment could $\frac{0}{7}$ usefully be incorporated into this study for further analysis.

We thank the Colt Foundation for its generogs financial support of this analysis, SCRATA and the HSE for their previous financial support and currem technical help, Antony Fletcher for his importam work in this field of research, and Ann Balnaves for word processing and editing and checking the data. We also thank Sir Richard Doll for helpful comments on an earlier draft.

\section{References}

1 International Agency for Research on Cancer. Monograph on the evaluation of the carcinogenic risk to humans. Vol 34. Polynuclear aromatic compounds. Part 3 Industrial exposures in aluminium production, coal gasification, coke production, and iron and steel founding. Lyon: IARC, 1984.

2 Lloyd JW, Ciocco A. Long-term mortality study of steelworkers. I. Methology. J Occup Med 1969;11:299-310.

3 Lloyd JW, Lundin FE Jr, Redmond CK, Geiser PB. Long-term 윽 mortality study of steelworkers. IV. Mortality by work area. $J$ Occup Med 1970;12:151-7.

4 Lerer TJ, Redmond CK, Breslin PP, Salvin L, Rush HW. Long- 三. term mortality study of steel workers. VII. Mortality patterns $\mathrm{N}$ among crane operators. J Occup Med 1974;16:608-14.

5 Breslin P. Mortality among foundrymen in steel mills. In: N Lemen R, Dement JM, eds. Dusts and disease. Park Forest South, Il: Pathatox Publishers Inc, 1979:439-47.

6 Redmond CK, Wieand HS, Rockette HE, Sass R, Weinberg G. Long-term mortality experience of steelworkers. Cincinnati $\mathrm{OH}: 0$ National Institute for Occupational Health, 1981. (DHHS publ $\frac{\mathrm{C}}{\mathrm{D}}$ No 81-120.)

7 Gibson ES, Martin RH, Lockington JN. Lung cancer mortality in ? a steel foundry. J Occup Med 1977;19:807-12.

8 Decoufle $P$, Wood DJ. Mortality patterns among workers in a gray 
iron foundry. Am J Epidemiol 1979;109:667-75.

9 Egan B, Waxweiler RJ, Blade L. Wolfe J, Wagoner JK. A preliminary report of mortality patterns among foundry workers. J Environ Pathol Toxicol 1979;2:259-72.

10 Egan-Baum E, Miller BA, Waxweiler RJ. Lung cancer and other mortality patterns among foundrymen. Scand $J$ Work Environ Health 1981;7,suppl 4:147-55.

11 Koskela RS, Hernberg S, Karava R, Jarvinen E, Nurminen M. A mortality study of foundry workers. Scand $J$ Work Environ Health 1976;2,suppl 1:73-89.

12 Tola S, Koskela RS, Hernberg S, Jarvinen E. Lung cancer mortality among iron foundry workers. J Occup Med 1979;21:753-60.

13 Fletcher AC, Ades A. Lung cancer mortality in a cohort of English foundry workers. Scand J Work Environ Health 1984;10:7-16.

14 Cox DR. Regression models and life-tables. Journal of the Royal
Statistical Society 1972;B34:187-219.

15 Kneale GW, Mancuso TF, Stewart AM. Hanford radiation study III: a cohort study of the cancer risks from radiation to workers at Hanford (1944-77 deaths) by the method of regression models in life-tables. $\mathrm{Br}$ J Ind Med 1981;38:156-66.

16 Sorahan T, Waterhouse JAH. Mortality study of nickel-cadmium battery workers by the method of regression models in lifetables. Br J Ind Med 1983;40:293-300.

17 Sorahan T, Parkes HG, Veys CA, Waterhouse JAH. Cancer mortality in the British rubber industry: $1946-80 . \mathrm{Br} \mathrm{J} \mathrm{Ind} \mathrm{Med}$ 1986;43:363-73.

18 Sorahan T, Burges DCL, Waterhouse JAH. A mortality study of nickel/chromium platers. Br J Ind Med 1987;44:250-8.

19 Fox AJ, Collier PF. Low mortality rates in industrial cohorts due to selection for work and survival in the industry. Br J Prev Soc Med 1976;30:225-30.

\section{Vancouver style}

All manuscripts submitted to the $\mathrm{Br} J$ Ind $\mathrm{Med}$ should conform to the uniform requirements for manuscripts submitted to biomedical journals (known as the Vancouver style)

The $B r J$ Ind Med, together with many other international biomedical journals, has agreed to accept articles prepared in accordance with the Vancouver style. The style (described in full in $\mathrm{Br}$ Med J, 24 February 1979, p 532) is intended to standardise requirements for authors.

References should be numbered consecutively in the order in which they are first mentioned in the text by Arabic numerals above the line on each occasion the reference is cited (Manson ${ }^{1}$ confirmed other reports ${ }^{2-5} \ldots$.). In future references to papers submitted to the $\mathrm{Br} J$ Ind Med should include: the names of all authors if there are six or less or, if there are more, the first three followed by $e t$ al; the title of journal articles or book chapters; the titles of journals abbreviated according to the style of Index Medicus; and the first and final page numbers of the article or chapter.

Examples of common forms of references are:

1 International Steering Committee of Medical Editors. Uniform requirements for manuscripts submitted to biomedical journals. Br Med J 1979;1:532-5.

2 Soter NA, Wasserman SI, Austen KF. Cold urticaria: release into the circulation of histamine and eosino-phil chemotactic factor of anaphylaxis during cold challenge. $N$ Engl J Med 1976;294:687-90.

3 Weinstein L, Swartz MN. Pathogenic properties of invading micro-organisms. In: Sodeman WA Jr, Sodeman WA, eds. Pathologic physiology: mechanisms of disease. Philadelphia: W B Saunders, 1974:457-72. 